\title{
The Role of Papanicolaou Test in the Diagnosis of Endometrial Carcinoma
}

\section{Endometrial Karsinom Tanısında Papanicolaou Testinin Rolü}

Gulay Turan ${ }^{1}$

Akin Usta ${ }^{2}$

${ }^{1}$ Balikesir University, Faculty of Medicine, Department of Pathology, Balikesir, Turkey ${ }^{2}$ Balikesir University, Faculty of Medicine, Department of Obstetrics and Gynecology, Balikesir, Turkey

Geliş Tarihi/Received: 11 November 2018 Kabul Tarihi/Accepted: 4 March 2019

Address correspondence to: Gulay Turan, Balikesir University, Faculty of Medicine, Department of Pathology, Balikesir, Turkey e-mail: gulaytr@yahoo.com.tr

\section{ORCID}

Gulay Turan

https://orcid.org/0000-0002-3702-8811

\begin{abstract}
Öz
Amaç: Pap smear testi, serviks kanseri ve öncü lezyonlarını taramak için en sık kullanılan ve etkili bir tarama yöntemidir. Endometrial karsinomların tanısında Pap smear testinin kullanımı ile ilgili çok az çalışma vardır. Biz bu çalışmada endometrial karsinom tanısı almış hastaların Pap smearlerinde atipik endometrial hücrelerin bulunma oranını ve klinikopatolojik parametrelerle korelasyonunu araştırmayı amaçladık.

Hastalar ve Yöntem: Bu çalışmada Ocak 2015-Eylül 2017 yılları arasında endometrial karsinom tanısı konulmuş ve aynı zamanda Pap smear örneklemesi yapılmış hastalar retrospektif olarak incelenmiştir. Endometrial karsinom olgularının histolojik tip, nükleer derece ve Pap smear sonuçları değerlendirilmiştir. Bulgular: Çalışmaya dahil edilen endometrial karsinom tanısı konulmuş 97 hastanın 59'una aynı zamanda smear örneklemesi yapılmıştı. Smear örneklemesi yapılan hastaların yaşları 42-82 yas aralı̆̆ındaydı (ortalama57,43 $\pm 9,08$ ). Hastaların menopoz durumu değerlendirildiğinde 12'si (\%20.3) premenopozal ve 47 'si (\%79.7) postmenopozal durumdaydı. En sık görülen histolojik tip endometrioid olup 51 hastada izlendi (\%86.4). 6 hastada seröz (\%10), 1 hastada şeffaf hücreli (\%1.8) ve 1 hastada müsinöz karsinom (\%1.8) mevcuttu. Pap smear sonucu 24 hastada atipik iken (\%40.7), 35 hastada normaldi $(\% 59.3)$. Nükleer derece değerlendirildiğinde 24 hastada derece 1 (\%40.7), 25 hastada derece $2(\% 42.3), 10$ hastada derece 3'tü (\%17). Tümör derecesi arttıkça Pap smearlerde atipik endometrial hücre görülme oranı artmaktaydı.

Sonuç: Endometrial karsinomlarda pap smear de atipik hücre saptama oranlarının azımsanmayacak kadar yüksek olduğu görüldü. Nonendometrioid ve yüksek dereceli karsinomlarda atipik hücre görülme oranları daha fazlaydı.
\end{abstract}

Anahtar Kelimeler: Endometrial karsinom, papanicolaou, smear

\section{Abstract}

Aim: Pap smear test is a commonly used and effective screening method in detection of cervical cancer and its precursor lesions. There is a very limited number of studies on use of Pap smears in diagnosis of the endometrial carcinomas. We have aimed to investigate the incidence rate of atypical endometrial cells in Pap smears of the patients diagnosed with endometrial carcinoma and the correlation between these cells and clinicopathological parameters.

Patients and Methods: In this study, patients who were diagnosed with endometrial carcinoma and who had smear sampling between January 2015 and September 2017 were examined retrospectively. Histological type, nuclear grade and Pap smear results of endometrial carcinoma cases were evaluated. Results: Pap smear sampling was concurrently performed in 59 of the 97 patients diagnosed with endometrial carcinoma. The ages of the patients who underwent smear sampling ranged between 42 and 82 years (mean 57.43 \pm 9.08 years). The menopausal status evaluation of the women revealed that 12 $(20.3 \%)$ and $47(79.7 \%)$ patients were premenopausal and postmenopausal, respectively. Endometrioid type carcinoma was encountered in $51(86.4 \%)$ patients as the most commonly found histological type. Serous, clear cell and mucinous carcinomas were determined in $6(10 \%), 1(1.8 \%)$ and $1(1.8 \%)$ patients, respectively. The results of Pap smear tests were atypical in $24(40.7 \%)$ patients whereas normal results were obtained in $35(59.3 \%)$ patients. Nuclear grade assessment of the carcinomas showed that grade 1, grade 2 and grade 3 carcinomas were discovered in 24 (40.7\%), 25 (42.3\%) and 10 (17\%) patients, respectively. The rate of the atypical endometrial cells encountered by Pap smears has increased as grade of the tumors increased.

Conclusion: We have concluded that the detection rate of atypical cells by Pap smear in endometrial carcinomas is considerably high. The incidence of atypical cells is higher in nonendometrioid and highgrade carcinomas.

Key words: Endometrial carcinoma, papanicolaou, smear

\section{INTRODUCTION}

A significant increase was detected in the worldwide incidence of endometrial carcinoma after the second half the twentieth century. The rate of the increased incidence is remarkable especially in the recent 30 years (1). Annually 142,000 new cases of endometrial carcinoma are diagnosed and 42,000 of those cases result in deaths $(1,2)$.

Although, endometrial carcinoma is the fourth most common type of cancer after breast, colorectal and lung cancers, it ranked eighth as a cancer type causing death (1). It is estimated that endometrial carcinoma may develop in $1-3 \%$ of the women in their lifetime (3). Endometrial carcinomas are usually
Cite this article as: Turan G, Usta A. The Role of Papanicolaou Test in the Diagnosis of Endometrial Carcinoma. Selcuk Med J 2019;35(3): 176-179
Disclosure: None of the authors has a financial interest in any of the products, devices, or drugs mentioned in this article. The research was not sponsored by an outside organization. All authors have agreed to allow full access to the primary data and to allow the journal to review the data if requested. 
diagnosed between the ages 50-65 years and mean age of diagnosis is 60 years old (4). The mortality rate of the endometrial adenocarcinomas seem to be considerably reducable by early diagnosis (5). However, there is no available standard imaging test for early diagnosis of endometrial carcinomas. Pap smear test has been used to detect premalignant and malignant lesions of the cervix since a long period of time (6). Bethesda 2001 system recommends to report the benign endometrial cells in all women aged over 40 years old regardless of their menopausal status and this age level was subsequently elevated to 45 years of age and over by Bethesda in 2014 (7). Exfoliated endometrial cells may be considered to be normal during menstruation and proliferative phases by Pap smear. However, a more comprehensive assessment should be performed if this type of cells are encountered in the postmenopausal women (8). In the literature, some studies have demonstrated that reporting endometrial cells detected in the cervical screening by Pap smear test may be significant with respect to endometrial carcinoma.

We have aimed to investigate the incidence rate of atypical endometrial cells in Pap smears of the patients diagnosed with endometrial carcinoma and the correlation between these cells and clinicopathological parameters.

\section{PATIENTS AND METHODS}

In this study, endometrial carcinoma was diagnosed in 97 of totally 984 patients who have consulted to the Gynecology and Obstetrics Polyclinic of our hospital between January 2015 to September 2017 due to the complaints of dysfunctional uterine bleeding, postmenopausal bleeding and menometrorrhagia, and who underwent an endometrial curettage. Of those, 59 of these patients were concurrently performed smear sampling. The microscope slides of the endometrial curettage samples stained with hematoxylin-eosin and Papanicolaou-stain smear preparations of the cases from our archive were reassessed. Histological typing and nuclear grading of the endometrial carcinoma cases were performed. The Pap smear results were divided into two groups as normal and atypical.

\section{Statistical analysis}

The data obtained from this study were transferred to the SPSS program (Version 20.0; SPSS Inc., Chicago, IL, USA) and then analysed. The number, percentage, mean and standard deviation values were utilized for the evaluation of descriptive statistics.

\section{RESULTS}

The ages of the 59 patients diagnosed with endometrial carcinoma in whom smear samplings were performed ranged between 42 and 82 years (mean $57.43 \pm 9.08$ years). The menopausal status evaluation of the women revealed that $12(20.3 \%)$ and $47(79.7 \%)$ patients were premenopausal and postmenopausal, respectively. Endometrioid type carcinoma was encountered in 51 (86.4\%) patients as the most commonly encountered histological type. Serous, clear cell and mucinous carcinomas were determined in $6(10 \%), 1(1.8 \%)$ and $1(1.8 \%)$ patients, respectively. The results of Pap smear tests were atypical in $24(40.7 \%)$ patients whereas normal results were obtained in $35(59.3 \%)$ patients. In $31.4 \%$ of patients with endometrioid type carcinoma, $87.5 \%$ of the patients with non-endometrioid type carcinoma had atypical cells in smear samples. As a result, the incidence of atypical cells increased in non-endometrioidal carcinoma. In $25 \%$ of the smear samples of premenopausal patients, atypical cells were observed, while $44.7 \%$ of postmenopausal patients had atypical cells. Nuclear grade assessment of the carcinomas showed that grade 1 , grade 2 and grade 3 carcinomas were discovered in 24 (40.7\%), 25 $(42.3 \%)$ and 10 (17\%) patients, respectively (Table 1). The rate of the atypical endometrial cells encountered in Pap smears has increased as grade of the tumors increased. There were no typical endometrial cells in the smear specimens examined.

\section{DISCUSSION}

Despite decreased number of invasive cervical cancers, endometrial carcinoma has become the

Table 1. Distribution of Pap smear results according to some clinicopathological parameters

\begin{tabular}{lll}
\hline $\begin{array}{l}\text { Clinico-pathological } \\
\text { parameters } \mathbf{n = 5 9}\end{array}$ & \multicolumn{2}{c}{ Pap smear result } \\
& Normal & Atypical \\
\hline $\begin{array}{lll}\text { Menopausal status } \\
\text { Premenopausal }\end{array}$ & $9(75 \%)$ & $3(25 \%)$ \\
$\begin{array}{l}\text { Postmenopausal } \\
\text { Histological Type }\end{array}$ & $26(55.3 \%)$ & $21(44.7 \%)$ \\
Endometrioid & $34(66.7 \%)$ & $17(33.3 \%)$ \\
Nonendometrioid & $1(12.5 \%)$ & $7(87.5 \%)$ \\
Nuclear Grade & & \\
Grade 1 & $20(83.3 \%)$ & $4(16.7 \%)$ \\
Grade 2 & $11(44 \%)$ & $14(56 \%)$ \\
Grade 3 & $1(10 \%)$ & $9(90 \%)$ \\
\hline
\end{tabular}




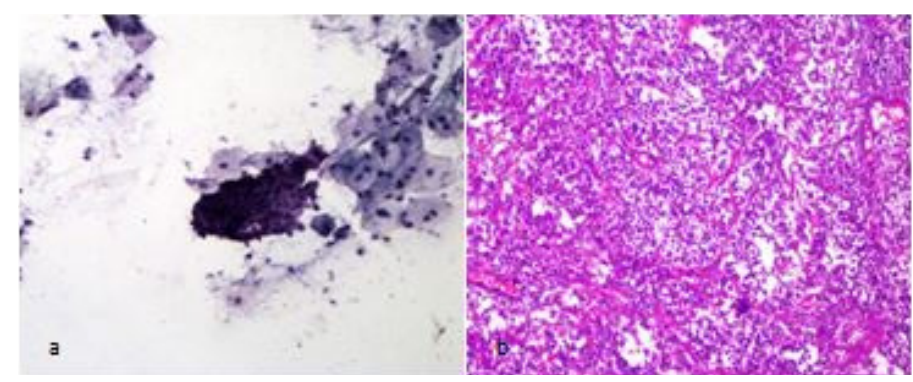

Figure 1. a) Atypical clustered endometrial cells with ovoid-round nuclei, thin-granular chromatin and pink-colored cytoplasms encountered by Pap smear b) endometrioid carcinoma grade 3

most frequently seen gynecologic cancer type (9). No effective screening method to detect endometrial carcinoma has been identified yet (10). Endometrial sampling is the most commonly used screening technique in the present time (11). Normal and atypical endometrial cells may be detected by Pap smear (12). Normal endometrial cells may be detected by Papsmear in some circumstances such as endometrial polyps, atypical and non-atypical hyperplasia, low and high grade adenocarcinoma, leiomyomas, proliferative endometrium, postpartum period, early period after abortion, acute endometritis, recently performed intrauterine intervention, use of intrauterine device, cervical and vaginal endometriosis (13).

Many studies have investigated the importance of the normal endometrial cells (NEC) discovered by Pap smear test in the postmenopausal women. Chang et al. (14) have analyzed 297 postmenopausal woman with NEC in a study and reported endometrial lesion in 14 ( $9 \%$ ) of the 132 women who underwent an endometrial biopsy whereas they detected cervical atypia and cancer in only 3 cases. In another study, Sarode et al. (15) have encountered endometrial pathology in $28(34 \%)$ of the 81 postmenopausal women with NEC detected by Pap smear test and reported that 4 $(4.9 \%)$ of those were endometrial carcinoma. Benign endometrial findings, polyps, simple hyperplasia, atypical hyperplasia and carcinoma were reported in $22-97 \%, 1-41 \%, 1-20 \%, 0.6-8 \%$ and $1-15 \%$ of the women with NEC identified by Pap smear test in many studies, respectively(15-17). In our study, the rates of atypical cells were higher in the smear samples of postmenopausal patients.

Shin et al. (18) have carried out a study on 108 cases with endometrial cancer and discovered abnormal cervical cytology in $38 \%$ of the patients with endometrial carcinoma. They have attributed the weak detection strength of cervical cytology for cancer to the fact that tumor cells do not easily integrate from the endometrium especially in the course of early-stage endometrial carcinoma. They have also demonstrated in their study that endometrial cancer cases with abnormal preoperative cervical cytology reveal higher tumor grade, advanced stage, nonendometrioid histological type, deeper myometrial invasion, cervical involvement, lymphovascular invasion and polypoid growth characteristic. However, Brown et al. (19) have emphasized that abnormal preoperative cervical cytology alone is not a prognostic factor and that it should not be considered in making treatment decisions. In the present study, detection rates of cervical smear for atypical endometrial cell in the course of endometrioid type endometrial carcinoma and non-endometrioid type endometrial carcinoma were $33.3 \%$ and $87.5 \%$, respectively. Atypical endometrial cells were encountered by Pap smear test in $16.7 \%, 56 \%$ and $90 \%$ of grade 1 , grade 2 and grade 3 tumors, respectively.

Jones et al. (20) have evaluated 143 cases and discovered benign pathological changes in 51 $(35.66 \%)$ cases. These changes included endometrial polyp, simple hyperplasia, atypical hyperplasia, leiomyoma, adenomyosis, atypical clear cell, adenomyosis with leiomyoma, polyp with leiomyoma, hyperplastic polyp, polyp with adenomyosis in respectively $23,8,2,6,1,1,5,2,2$ and 1 cases. Of the 143 cases, $5(3.50 \%)$ showed endometrial carcinoma. They have shown in the same study that endometrial pathologies increased with female age. Polyps and atypical endometrial hyperplasia were found in higher frequencies as benign findings. They have found that cytologic presence of NECs in Pap smears of the postmenapausal women indicates a pathological condition and needs follow-up.

The detection sensitivity of Pap smear for atypical endometrial cell in the endometrial carcinomas has been reported between $40 \%$ to $70 \%$ (21). Fukuda et al. (22) have reported that Pap smear had a detection sensitivity rate of $31.3 \%$ for atypical endometrial cell in the patients with endometrial carcinoma. Asma et al. (12) have determined a detection rate of $70 \%$ for atypical endometrial cells by Pap smear and attributed this high rate to the presence of high grade tumors in the most cases. Of our cases, $86.4 \%$ were endometrioid and $13.6 \%$ were non-endometrioid (6 serous, 1 mucin and 1 clear cell carcinoma, respectively). We found atypical endometrial cell in 
$40.7 \%$ of cases with pap smear sampling.

Our results indicate that Pap test may play an important role in the diagnosis of nonendometrioid type and high grade endometrial carcinoma. The limitations of our study were the use of conventional Pap smears and the low number of samples. There are few studies on the use of pap smear in the diagnosis of endometrial carcinoma. These studies should be supported by liquid-based cytology and molecular studies.

Conflict of interest: Authors declare that there is no conflict of interest between the authors of the article.

Financial conflict of interest: Authors declare that they did not receive any financial support in this study.

Address correspondence to: Gulay Turan, Balikesir University, Medicine Faculty, Department of Pathology, Balikesir, Turkey

e-mail: gulaytr@yahoo.com.tr

Phone: 2666121010

\section{REFERENCES}

1. Siegel R, Ward E, Brawley O, et al. Cancer statistics, 2011: The impact of eliminating socioeconomic and racial disparities on premature cancer deaths. CA: A cancer journal for clinicians 2011;61(4):212-36.

2. Jass JR. Classification of colorectal cancer based on correlation of clinical, morphological and molecular features. Histopathology 2007;50(1):113-30.

3. Sood A, Buller R, Burger R. Value of preoperative CA-125 level in the management of uterine cancer and prediction of cliniczl outcome. Obstet Gynecol 1997;90(3):441.

4. Whitaker GK, Lee RB, Benson WL. Carsinoma of the endometrium in young women. Milit Med 1986;151:25.

5. Ellenson LH, Ronnet BM, Soslow RA, et al. Endometrial carcinoma. Kurman RJ, Ellenson LH, Ronnet BM (eds). In: Blaustein's pathology of the female genital tract. New York: Springer, 2011:393-402.

6. Thrall MJ, Kjeldahl KS, Kay Savik K, et al. Significance of benign endometrial cells in Papanicolaou tests from women aged >or= 40 years. Cancer 2005;105(4):207-16.

7. Simsir A, Carter W, Elgert $P$, et al. Reporting endometrial cells in women 40 years and older-assessing the clinical usefulness of Bethesda 2001. Am J Clin Pathol 2005;123: 571-5.

8. Lai CR, Hsu CY, Hang JF, Li AFY. The diagnostic value of routine Papanicolaou smears for detecting endometrial cancers; An update. Acta Cytologica 2015;59(4):315-8.

9. Greenlee RT, Hill-Harmon MB, Murray T, et al. Cancer statistics, 2001. CA Cancer J Clin 2001;51(1):15-36

10. Moriarty AT, Cibas ES. Endometrial cells: The how and when of reporting. Solomon D, Nayar R, (eds). In: The bathesda system for reporting cervical cytology: Definitions, criteria, and explanatory notes. New York: Springer-Verlag, 2004:5765.

11. Canavan TP, Doshi NR. Endometrial cancer. Am Fam Physician 1999;56:3069-77.
12. Asma Nadaf, Hephzibah Rani, Parinitha SS, et al. Pap Smears in endometrial adenocarcinoma: Does it have a role? Asian Pac J Cancer Prev 2017;18(4):1145-50.

13. $\mathrm{Ng} \mathrm{AB}$, Reagan JW, Hawliczek S, et al. Significance of endometrial cells in the detection of endometrial carcinoma and its precursors. Acta Cytol 1974;18(5):356-61.

14. Saad RS, Mahdavy M, Takei $\mathrm{H}$, et al. Endometrial cells in cervical specimens of women 940 years of age. Acta Cytol 2004;48:678-9.

15. Sarode vR, Rader AE, Rose PG, et al. Significance of cytologycally normal endometrial cells in cervical smears from postmenopausal women. Acta Cytol 2001;45(2):153-6.

16. Chang A, Sandweiss L, Bose S. Cytologycally benign endometrial cells in the Papanicolaou smears of postmenopausal women. Gynecol Oncol 2001;80(1):37-43.

17. Mount SL, Wegner EK, Eltabbakh GH, et al. Significant increase of benign endometrial cells on Papanicolaou smears in women using hormone replacement therapy. Obstet Gynecol 2002;100(3):445-50.

18. Shin DH, choi uK, Suh DS, et al. Implication of preoperative cervical cytology in endometrial carcinoma. Basic and Applied Pathology 2009;2:30-4.

19. Brown AK, Gillis S, Deuel c, et al. Abnormal cervical cytology: A risk factor for endometrial cancer recurrence. Int J Gynecol Cancer 2005;15(3):517-22.

20. Jones E, McGahey Frain B, Crabtree W. Clinical significance of reporting benign-appearing endometrial cells in pap tests in women aged 40 years and over. Acta Cytol 2009;53:18-23.

21. Gu M, Shi W, Barakat RR, et al. Pap smears in women with endometrial carcinoma. Acta Cytol 2001;45(4): 555-60.

22. Fukuda K, Mori M, Uchiyama M, et al. Preoperative cervical cytology in endometrial carcinoma and its clinico-pathologic relevance. Gynecol Oncol 1999;72:273-7. 